\title{
The Implementation of Highly Immersive Programme (HIP) Speaking Activities in Malaysian Schools: A Literature Review
}

\author{
Siti Rafidah Kamsin, Maslawati Mohamad* \\ Faculty of Education, Universiti Kebangsaan Malaysia, Bangi, Malaysia \\ Email: ${ }^{*}$ maslawati@ukm.edu.my
}

How to cite this paper: Kamsin, S. R., \& Mohamad, M. (2020). The Implementation of Highly Immersive Programme (HIP) Speaking Activities in Malaysian Schools: A Literature Review. Creative Education, 11, 1783-1794.

https://doi.org/10.4236/ce.2020.119130

Received: August 25, 2020

Accepted: September 21, 2020

Published: September 24, 2020

Copyright $\odot 2020$ by author(s) and Scientific Research Publishing Inc. This work is licensed under the Creative Commons Attribution International License (CC BY 4.0).

http://creativecommons.org/licenses/by/4.0/

\begin{abstract}
English is the second language in Malaysia and it is a compulsory subject to be learnt in all schools. On average, Malaysian pupils spend at least 11 years learning the subject formally in classrooms before pursuing their education at the tertiary level or joining the workforce. However, from numerous reports, it is found that Malaysian pupils are still struggling to master the language thus affecting their performance in studies and depriving them of good job opportunities. Therefore, the Ministry of Education introduced the Highly Immersive Programme (HIP) which was implemented in all schools starting from 2016. It is a programme under the MBMMBI (Upholding the Malay Language and Strengthening Command of English) policy that will enhance pupils' proficiency in English through increased exposure to the language in schools. This paper provides a literature review on the Highly Immersive Programme (HIP) speaking activities and its implementation in Malaysian schools. It includes reports on pupils' lack of proficiency in the language, the implementation of the Highly Immersive Programme and previous studies carried out regarding its implementation.
\end{abstract}

\section{Keywords}

English as a Second Language, Highly Immersive Programme (HIP), MBMMBI (Upholding the Malay Language and Strengthening Command of English), English Proficiency

\section{Introduction}

English language has been the lingua franca for decades and it is used in many countries around the globe. Its importance in international businesses and trades, as well as cultural interactions, is undeniable thus making it an essential 
language that is mastered by a majority of people around the world. Malaysia has accorded English as a second language status as stated in Article 152 of the Federal Constitution and given due attention (Azmi, 2013). As the demands of mastering the language in pursuing education, fulfilling the needs of employment or simply to communicate in informal settings is rapidly increasing. Malaysians need to be proficient in English. In this era of global competitiveness, the mastery of English is essential for pupils to equip themselves with the necessary skills in order to keep pace in a rapidly emergent global economy (Ministry of Education Malaysia, 2018).

The Malaysian education system has made the English Language a compulsory subject to be learnt in all primary and secondary schools in Malaysia, starting from Year 1 in primary school to Form 5 in secondary school (Ministry of Education Malaysia, 2013). As outlined in Standard Curriculum for Secondary School, as future leaders, pupils need to improve their proficiency in English, as well as leadership qualities and ethical decision-making skills in order to be globally competitive (Ministry of Education Malaysia, 2000). On average, 11 years is spent to learn English language throughout their formal schooling life. It also means they learn to listen, speak, read and write in the language.

There are four main skills which need to be mastered in English language to enable one to be proficient, namely listening, speaking, reading and writing skills. As one of the productive skills, speaking is considered by many to be the fundamental skill in second language learning (Celce-Murcia, Brinton, \& Snow, 2014). Most of the time, one's fluency in English language is proven by the ability to speak and communicate well in the language.

Compared to other skills, speaking is considered to be the most difficult to master as it would usually need spontaneous response especially in real-life situations. According to Celce-Murcia, Brinton, and Snow (2014), the act of speaking is staggeringly complex, as the speaker needs to monitor and understand other speaker(s), think about one's own contribution, producing that contribution, monitoring its effect and so on. Thus, the ability to respond aptly in authentic situations would also mean one has already acquired a substantial amount of the language needed and becomes a fluent English language user.

This is supported by McDonough, Shaw, \& Masuhara (2013). They stated that speaking is not the oral production of written language, but involves the learner in the mastery of a wide range of subskills, which, added together, constitute an overall competence in the spoken language. Another crucial factor in enhancing speaking ability is to practise using the language. As the learner speaks the target language more often, he or she would become more proficient in speaking the language. According to Harmer (2001), repetition allows the students to improve on what they did before. He suggested that it is important for students who have made an oral presentation to repeat in another setting so that they do it better. Some good examples of speaking activities are acting from a script, communication games, discussion, prepared talks and role-play (Harmer, 2001). 
In Malaysia, despite having ample time learning to be proficient in English language, it is found that a huge number of Malaysian pupils are still struggling to speak in English thus depriving them of the best offers they could get especially in pursuing their education at tertiary level or in getting a decent job after they leave school. For example, it is reported in the Malaysia Education Blueprint (2013-2025) that the operational proficiency in English is much lower than the expected level. Next, it is found that the high unemployment rate (in Malaysia) among graduates is often attributed to their lack of English proficiency and communication skills (Ting, Marzuki, Chuah, Misieng, \& Jerome, 2017; Selvaratnam, 2018).

In the effort to enhance pupils' proficiency in English language, the Ministry of Education Malaysia has taken significant measures especially in improving the existing education policy. For instance, the introduction of the Upholding the Malay Language and Strengthening Command of English (MBMMBI) policy under the Curriculum programme in 2011 and 2012, with an objective to form a society which has the mastery of both Bahasa Melayu (Malay language) and English Language in the nation's education system (Ministry of Education Malaysia, 2017). Next, in 2013, the Malaysia Education Blueprint (2013 to 2025) was established by the Ministry of Education Malaysia. One of the attributes described in this document is every child will be, at minimum, operationally proficient in Bahasa Melayu (Malay language) as the national language and language of unity, and in English as the international language of communication.

With the enhancement of the Education Policy, the Highly Immersive Programme (HIP) was introduced under the MBMMBI policy in 2016 and by 2018, this programme was implemented in all Malaysian schools. The main objective is to create a highly immersive, language-rich environment that promotes the use of English in all schools in Malaysia (Ministry of Education Malaysia, 2017: p. 79).

The implementation of the Highly Immersive Programme is according to a process, which consists of 6 steps. The process starts with identifying the respondents for an assessment tool and ends with collecting evidences of students' performance. The process continues in the next cycle when the sixth step is completed.

The following figure is adapted from the HIP Toolkit by the Ministry of Education Malaysia (2016a). The process shown in this figure (Figure 1) is used as a reference, especially for teachers in schools in implementing the programme, so that at the end of the process, the aim of enhancing pupils' proficiency level in English language is achieved.

Another important element of the Highly Immersive Programme is the active involvement of its stakeholders which refer to the principal, teachers, parents and the community. This programme requires everybody in a child's immediate surrounding to take part in creating a conducive environment for the child to use English language not only in classrooms during English lessons or in the 


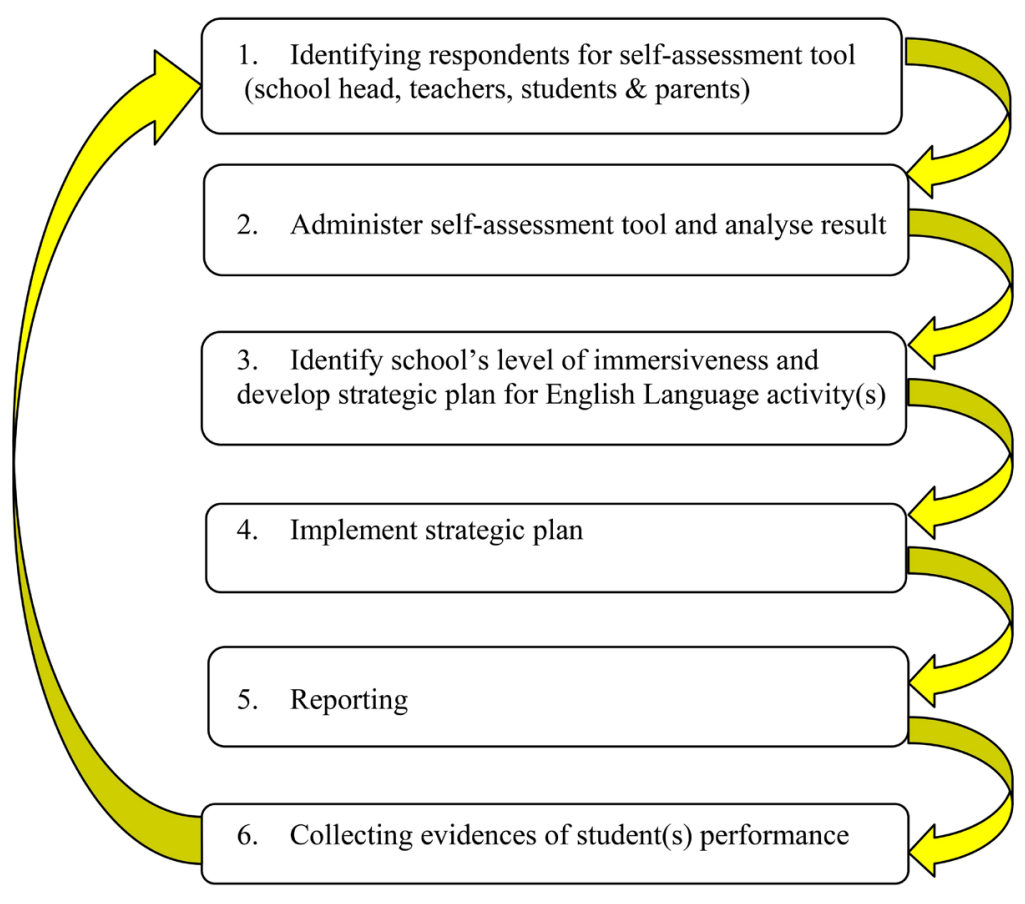

Figure 1. The Highly Immersive Programme (HIP) Implementation Process in Malaysian schools.

school compound, but also daily his/her life outside the school (Ministry of Education Malaysia, 2016a). At school, all pupils are given the opportunities and expected to be involved in activities that require them to use English language. Thus, it is hoped that with the implementation of this programme, pupil's proficiency level in English language could improve and give him/her more chances to excel at the tertiary or employment level.

This paper provides a literature review on the implementation of Highly Immersive Programme (HIP) speaking activities in Malaysian schools. This literature review study will attempt to provide answers to the following research questions:

1) What are the issues in English language proficiency among Malaysian pupils?

2) What are the outcomes of HIP implementation in Malaysian schools?

In order to answer the research questions, the researcher conducted a library research on the issues of language proficiency among Malaysian pupils and the implementation of Highly Immersive Programme (HIP) in Malaysian schools. It is conducted by the researcher as the issue of pupils' lack of proficiency in English is not a recent phenomenon, but has been existing for several years. At the same time, the researcher hoped to find possible benefits of the Highly Immersive Programme (HIP) so that it could be enforced more effectively in Malaysian schools. Finally, the aspiration of increasing pupils' proficiency level especially in speaking skill would be realized at the end of their formal schooling years with an effective implementation of the Highly Immersive Programme. 


\section{Literature Review}

\subsection{Issues in English Language Proficiency}

The issue of Malaysian pupils' lack of proficiency in English language has been a pressing matter especially among the teachers and policymakers in the education sector. In dealing with the issue, the Ministry of Education Malaysia has taken several significant measures such as the implementation of MBMMBI and adopting CEFR (the Common European Framework of Reference for Languages) into the English education system as outlined in The Roadmap (2015-2025). The following paragraphs are a discussion on pupils' lack of proficiency in Malaysian schools which has somehow deprived them of great opportunities in their future.

One of the major concerns related to pupils' lack of proficiency in English language is that a huge number of them are still struggling to speak in English thus depriving them of the best offers they could get especially in pursuing their education to tertiary level or in getting a decent job after they leave school. In the Malaysia Education Blueprint (2013-2025), it is reported that the operational proficiency in English is very low whereby only $28 \%$ of students achieved a minimum credit in the 2011 SPM English paper against Cambridge 1119 standards. Poor English proficiency among fresh graduates, since 2006, has also been consistently ranked as one of the top five issues faced by Malaysian employers.

Next, concerning the report in the Malaysian Education Blueprint (2013-2025), it is reported in the media that generally, Malaysian students' proficiency level in English language is not up to the expected level. There are numerous reports on pupils' low proficiency level and underachievements in English language despite having spent more than 10 years learning the language in school.

For instance, as reported by Ting et al. (2017), the high unemployment rate (in Malaysia) among graduates is often caused by their lack of English proficiency and communication skills. Next, according to Selvaratnam (2018), poor command of English is recognised as the chief reason for employability decline. He pointed out that apart from their interpersonal and leadership skills, thousands of public university graduates were unemployable by the private sector primarily because of their lack of fluency in English.

Besides, similar issues have been raised in the news on pupils' incompetency in English language. According to a newspaper article by D'Silva (2019), natural timidity and fear of embarrassing themselves caused them to be reluctant to learn English. In another newspaper article by Aziz (2017), it was found that Malaysian students lacked the confidence to communicate using English. This was reported in the article that students all over the country were unable or unwilling to speak the English language.

Similarly, Mustafa (2018) reported that undergraduates are reluctant to express themselves due to lack of mastery in vocabulary although they comprehend what they heard and read. In another report in the Star newspaper dated 21 January 2017, Malaysia Employers Federation (MEF) executive director Datuk 
Shamsuddin Bardan commented that lack of basic knowledge in English language has deprived job seekers of the opportunities in getting the desired jobs. In addition, their preference for using the Malay language during interview sessions in English has further reduced their chances to secure a job. Next, according to Ujang (2019), the lack of English proficiency is always reported by employers as the main weakness among the job seekers.

These alarming reports indicate that the main issue of pupils' lack of proficiency in English language is their inability to speak the language in real-life situations thus depriving them of valuable chances in pursuing their education or getting a good job. Therefore, this indicates that there could be a serious weakness in the English language education which needs to be addressed efficiently especially by the policymakers and stakeholders in the education sector. By addressing any possible flaws or imperfections in the English language education system, it is hoped that Malaysian pupils' proficiency would improve.

In the process of improving the current situation, it is crucial to identify or perhaps to take into consideration the best strategy in enhancing pupils' proficiency level in English language. Numerous studies have been carried out in identifying possible reasons for second language learners' lack of proficiency in English language. The findings indicate some issues particularly pedagogical problems during the process of the teaching of English at schools. The first example is a study carried out by Khatib and Maarof (2015) involving 60 technical college students in Malaysia on speaking skills. The findings of this study suggest that it is crucial for teachers to give positive feedback and encouragement to enhance students' self-efficacy in oral communications.

There are also other similar studies on learners of English as a second or foreign language. For instance, a study was conducted on speaking skills involved 18 undergraduates from a university in Thailand who learnt English for at least 8 years before they entered university (Boonkit, 2010). It was found that the majority of the undergraduates were unable to speak in English confidently especially for meaningful interactions with international speakers. The findings indicate that the anxiety of making errors could have caused them to have low self-confidence to speak in English language.

The next related study involved 270 undergraduates on English language learning in Iran by Noori and Mazdayasna (2014). It was found that teacher-centred and lecture-based English literature classes should be replaced by communication-based classes which provide more opportunities for students' discussions and learning.

In addition, in another study which involved 50 learners of English as a second or foreign language in Macedonia, an investigation of motivation was carried out. The findings of this study suggest that when second language learners are involved more frequently in learning activities, they would be more active in social interactions and thus allowing personal transformation to take place (Kirova, Petkovska, \& Koceva, 2012).

The above studies are similar to the Malaysian context in the sense that Eng- 
lish language is officially learnt as a second language in schools, although for many pupils especially in rural areas, English is a foreign language. Nevertheless, significant findings from the studies above should be highlighted in relation to the HIP. For instance, educators should always motivate their students in learning a language as motivation plays an important role in enhancing their proficiency level. Next, being involved in communicative activities whereby pupils use language in real situations provides more opportunities for them to enhance their proficiency in the English language.

The findings of the abovementioned studies could be taken into consideration. The findings could serve as an important guideline in improving Malaysian pupils' proficiency level in English language. Therefore, there is a need of an effective programme in enhancing their proficiency level in English language by implementing the Highly Immersive Programme (HIP) in Malaysian schools.

\subsection{HIP Implementation in Malaysian Schools}

In accordance with the pressing need to address the issue of Malaysian pupils' improficiency in English language, a significant measure was taken by the Ministry of Education Malaysia. A programme called the Highly Immersive Programme (HIP) was firstly introduced in 2016 and was finally implemented in all schools in Malaysia in 2018.

The HIP is a programme under the MBMMBI policy that will improve pupils' proficiency in English through increased exposure to the language in schools (Ministry of Education Malaysia, 2016a). HIP allows a highly immersive language-rich environment to be developed for the pupils, for them to deliberately and recurrently be exposed to the English language through a variety of activities of high-quality linguistic input both within and beyond the classroom (Bunce, 1995 cited in Ministry of Education Malaysia, 2016a). It is an enhancement of the 1999 MOE circular on implementing English enrichment activities in and out of class to increase the pupils' exposure time to the language. Besides, the objective of the programme is also to instill positive behaviours towards the learning and usage of the English Language.

This programme is in line with the National Education Philosophy (1996), education in Malaysia which aims at producing learners who are holistic and competitive in the 21st century (Ministry of Education Malaysia, 2016b). Pupils need to prepare themselves to face globalisation where English is used as an important means of communication. Thus, there is an urgent need to provide a highly immersive English-rich environment in schools to enhance pupils' proficiency in the language. HIP is based on a whole-school approach, which involves its stakeholders which refer to school heads, teachers, students, parents and community. It is also significant to note that all teachers, regardless of the subjects they are teaching are directly involved in this programme to ensure its success.

The fundamental factors in the implementation of HIP in Malaysian schools, which refer to the school head, teachers, pupils, parents and community who 
should work hand in hand in enhancing pupils' proficiency in English language (Ministry of Education Malaysia, 2016a). Each of them is assigned specific roles and responsibilities in ensuring the success of the programme. Firstly, the school head plays the role of "the anchor" who is responsible for the whole process of the HIP implementation in the school (Ministry of Education Malaysia, 2016a). Next, the teachers, known as the "doer" organize effective activities that provide opportunities for the pupils to learn in a conducive English environment. Thirdly, the pupils or "the learners" are responsible for their own learning with the support from their teachers and parents. Finally, the parents and community as the "supporter" provide financial aid and appropriate support in carrying out the activities. Thus, each stakeholder has significant roles in ensuring the success of the programme (Ministry of Education Malaysia, 2016a).

A toolkit for the HIP is an important document which provides the guide on the implementation of the programme in Malaysian schools (Ministry of Education Malaysia, 2016a). A significant part of the document is suggested activities which could be carried out to realize the objectives of the programme such as "I’m In!", "Musical.ly", and "Dedication DD Corner" to name a few. These activities provide great opportunities for pupils to use English language communicatively, most preferably in authentic situations outside the classrooms, depending on the schools' planning (Jiew, 2017). When the pupils are involved in these activities, the focus would not be as much as on the form of the language, such as the grammatical rules which they usually learn formally in classrooms, but would be on how they would speak or write using the English language to ensure communication is taking place in accomplishing the task, and indirectly, the pupils are acquiring the language (Jiew, 2017).

Another essential part of the HIP Toolkit is the self-assessment tool which allows schools to reflect on their immersive levels in English (Ministry of Education Malaysia, 2016a). The tool is completed three times a year, in February, in the middle and at the end of the year to determine the progress the school has achieved by comparing the school's immersive levels at each completion (Ministry of Education Malaysia, 2016a). The respondents are all the stakeholders of the school, with a minimum of 5 respondents from each group, who need to respond to the items in the self-assessment tool. The tool is rated on a point Likert scale with a range of values starting from 1 (not at all) to 5 (very often) (Ministry of Education Malaysia, 2016a). In addition, the levels of immersiveness are also described in the toolkit as a guide for the school to identify their level of immersiveness and to plan and carry out necessary measures to improve the level, which indirectly would enhance the pupils' proficiency in English language. The levels of immersiveness range from 1 which refers to the lowest level of immersiveness to 4 which refers to the highest level of immersiveness in the school (Ministry of Education Malaysia, 2016a).

The above description of the Highly Immersive Programme (HIP) shows that it is a systematic programme devised by the Ministry of Education Malaysia with a sole purpose of improving the pupils' improficiency in English language. 
A few studies have been carried out regarding the implementation of the HIP in Malaysian schools. Firstly, a study by Matthew and Yamat (2020) entitled "Evaluation of Highly Immersive Program using CIPP" which was conducted in a semi-urban school in Bintulu, Sarawak. This study aimed at evaluating the implementation of Highly Immersive Programme (HIP) in that school, using the Context, Input, Process and Product (CIPP) model developed by Stufflebeam. It involved 261 respondents, namely the school head, teachers, pupils, parents and the community in the area. The findings of this study indicated that more support is needed from the stakeholders to improve the implementation of Highly Immersive Programme (HIP).

A similar study that adopted the CIPP model in evaluating the effectiveness of the implementation of HIP was carried out by Jiew (2017) which involved 223 participants of a school in Sarawak including the school head, teachers, pupils, parents and the community. The findings of the study showed that the implementation of HIP at the school mostly served its purpose to increase students' English language proficiency. However, some improvements in the dimensions of students' confidence, as well as support from parents and community, were required to make the programme more effective.

In addition, another study that evaluated to what extent the inputs supported the implementation of HIP was carried out in Terengganu, involving 154 HIP trainers and coordinators from the state and national levels (Mohd Noh, Abd Samad, Mohd Matore, \& Othman, 2019). The findings of the study reported there was lack of fund in implementing the programme and lack of cooperation from the teachers as only English teachers were appointed as the coordinator of the programme in most schools.

Next, a study on HIP which aimed to find major issues contributing to low performance of HIP in a school was carried out in a rural national school in Song, Sarawak (Racha \& Yunus, 2019). In this case study, the participants were 5 teachers who took part in a semi-structured interview and shared their opinions on factors contributing to the low performance of HIP in that school. The findings indicated that English proficiency among the pupils was identified as the main cause of the low performance of HIP implementation in the school, followed by school facilities, pupils' motivation, parents' participation and perceptions of programme.

Finally, Ansawi (2017) conducted a study entitled "Promoting the 3Es (Exposure, Experience, Engagement) in an English-rich Rural Primary School Community", in Tuaran, Sabah. This study involved 139 teachers and pupils, and the school focused on the English Village (SKREV), as a highly immersive programme and the effectiveness of the activities. From the findings, it is concluded that the programme was effective to improve the pupils' English communication proficiency due to the collaboration of the school, teachers, parents and the community.

From the above studies, it could be observed that the objective of the HIP to enhance pupils' proficiency in English can be achieved when the stakeholders of 
the schools work collaboratively in carrying out the activities planned for the pupils (Ansawi, 2017). In school, teachers play a significant role to motivate their pupils in the learning process to enhance their confidence in practicing the language frequently, thus, enhancing their fluency in English. As reported in a study by Jerang, Mohamad, \& Yunus, (2016), teachers should motivate the students to learn better English, by highlighting its importance as they need English for employment purposes in the future. This is further supported by Zulkiflei, Yunus, \& Hashim, (2017) that teachers need to provide a conducive and encouraging environment in language classrooms to allow the pupils to enjoy themselves in the learning process. Thus, teachers' role in enhancing pupils' fluency in the target language is a crucial factor in the success of the Highly Immersive Programme (HIP).

However, the lack of parents' involvement and support found in the research findings conducted by Jiew (2017) and Racha \& Yunus (2019) showed an undesirable result in improving pupils' proficiency level. Besides, most of the above studies indicated that the stakeholders play a crucial role in realizing the aim of the Highly Immersive Programme (HIP). When the stakeholders collaborate well, it enhanced pupils' proficiency level in English language.

\section{Conclusions and Implementations}

As stated earlier, this paper presents a literature review on the issues of English language proficiency among Malaysian pupils and one of the measures taken by the Ministry of Education to address the problem, is focusing on the implementation of the HIP. It is a pressing issue that Malaysian pupils are still incompetent to master the English language although it is a compulsory subject learnt in school. In addition, pupils spent a minimum of 10 years learning the language, and yet many of them failed to use the language efficiently especially in speaking. Their incompetency in the language becomes evident from their lack of performance in the subject in school and later their inability to secure good jobs or to pursue higher positions in their career when they have completed their studies, as reported by numerous sources.

The HIP is a significant initiative by the Ministry of Education especially in enhancing pupils' speaking proficiency in English language. Its implementation to all schools since 2016 is very much needed to realize the aim of the education policy of forming a society which has a mastery of both Bahasa Melayu (Malay language) and English language to be globally competitive. The activities suggested in the HIP Toolkit function as effective tools in achieving this objective. The involvement of all stakeholders in this programme could further accelerate the progress of the Highly Immersive Programme and most importantly would benefit the pupils.

However, from the few previous studies carried out on the HIP, the effectiveness of its implementation has yet to be confirmed. An important highlight from the previous studies is, when teachers and parents work hand in hand in con- 
ducting the HIP activities, the programme would be carried out successfully. Parents' strong support is a crucial factor in determining the success of the programme and most importantly enhancing pupils' proficiency in English language. In the long run, the aim of forming a society to be fluent in English language would become a reality.

This literature review implies that the stakeholders' role is vital in ensuring the success of the programme. As reported in previous studies, teachers and parents need to work together in carrying out the HIP activities in schools. Since the programme is known mainly by the school, parents should also be informed about the activities. They should be involved in the activities as they could contribute their expertise in this programme to make it a success. Next, more research should be carried out on the implementation of the HIP in order to assess its outcomes or to learn the best way on how to ensure its success especially in enhancing pupils' proficiency level in English language. Due to the lack of research done on the implementation of HIP in schools, not much is known on its real outcomes, thus, depriving the much needed details especially in improving the current practice in schools.

\section{Conflicts of Interest}

The authors declare no conflicts of interest regarding the publication of this paper.

\section{References}

Ansawi, B. (2017). Promoting the 3Es (Exposure, Experience, Engagement) in an English-Rich Rural Primary School Community. The English Teacher, No. 1, 13.

Aziz, H. (2017). Getting Students to Speak Up. New Straits Times, 2 August. https://www.nst.com.my/opinion/columnists/2017/08/263259/getting-students-speak

Azmi, M. N. L. (2013). National Language Policy and Its Impacts on Second Language Reading Culture. Journal of International Education and Leadership, 3, No. 1.

Boonkit, K. (2010). Enhancing the Development of Speaking Skills for Non-Native Speakers of English. Procedia-Social and Behavioral Sciences, 2, 1305-1309. https://doi.org/10.1016/j.sbspro.2010.03.191

Celce-Murcia, M., Brinton, D., \& Snow, A. (2014). Teaching English as a Second or Foreign Language (4th ed.). Boston, MA: Heinle ELT.

D’Silva, V. (2019). Challenges Students Mastery English. New Straits Times, 19 October. https://www.nst.com.my/news/nation/2019/10/531486/challenges-students-mastery-en glish

Harmer, J. (2001). The Practice of English Language Teaching. London: Longman. https://doi.org/10.1177/003368820103200109

Jerang, E. U., Mohamad, M., \& Yunus, M. M. (2016). A Study on Rural Secondary School Students' Perceptions of Their Motivation and Attitude towards Learning English. Worldconferences.net.

Jiew, F. F. (2017). The Evaluation of Highly Immersive Programme (HIP). International Journal of Academic Research in Business and Social Sciences, 7, 2222-6990.

Khatib, F. M. M., \& Maarof, N. (2015). Self-Efficacy Perception of Oral Communication Ability among English as a Second Language (ESL) Technical Students. Procedia-Social 
and Behavioral Sciences, 204, 98-104. https://doi.org/10.1016/j.sbspro.2015.08.121

Kirova, S., Petkovska, B., \& Koceva, D. (2012). Investigation of Motivation and Anxiety in Macedonia While Learning English as a Second/Foreign Language. Procedia-Social and Behavioral Sciences, 46, 3477-3481. https://doi.org/10.1016/j.sbspro.2012.06.088

Matthew, V. R., \& Yamat, H. (2020). Evaluation of Highly Immersive Program (HIP) Using CIPP Model. International Journal of Academic Research in Business and Social Sciences, 10, 509-526. https://doi.org/10.6007/IJARBSS/v10-i4/7152

McDonough, J., Shaw, C., \& Masuhara, H. (2013). Materials and Methods in ELT: A Teacher's Guide (3rd ed.). Hoboken, NJ: John Wiley \& Sons, Inc.

Ministry of Education Malaysia (2000). Bahasa Inggeris. Pusat Perkembangan Kurikulum: Kementerian Pendidikan Malaysia.

Ministry of Education Malaysia (2013). Blueprint 2013-2025 (p. 27). Kuala Lumpur: Ministry of Education.

Ministry of Education Malaysia (2016a). Toolkit for the Highly Immersive Programme Version $1.0(2016-2018)$.

Ministry of Education Malaysia (2016b). Blueprint 2013-2025 (2013) (p. 27). Kuala Lumpur: Ministry of Education.

Ministry of Education Malaysia (2017). Dasar Pendidikan Kebangsaan. Putrajaya: Bahagian Perancangan dan Penyelidikan Dasar Pendidikan. Edisi Keempat.

Ministry of Education Malaysia (2018). Kurikulum Standard Sekolah Menengah. Bahasa Inggeris. Dokumen Standard Kurikulum dan Pentaksiran Tingkatan 4.

Mohd Noh, M. F., Abd Samad, N., Mohd Matore, M. F., \& Othman, N. (2019). Penilaian Highly Immersive Programme (HIP) Sejauh mana sumber menyokong pelaksanaan program. In Prosiding Seminar Kebangsaan Pendidikan Negara (SKEPEN) ke-6 (pp. 1171-1189). Bangi, Selangor: Fakulti Pendidikan, UKM.

Mustafa, Z. (2018). Proficient Way to Better English. New Straits Times, 11 July. https://www.nst.com.my/education/2018/07/389562/proficient-way-better-english

Noori, M., \& Mazdayasna, G. (2014). A Triangulated Study of Target Situation Needs of Iranian Undergraduate Students of English Language and Literature. Procedia-Social and Behavioral Sciences, 98, 1374-1379. https://doi.org/10.1016/j.sbspro.2014.03.555

Racha, E., \& Yunus, M. M. (2019). Issues Contributing to Low Performance of Highly Immersive Programme (HIP) in a Rural National School in Song. In Proceeding: International Conference on Humanities, Education and Society (pp. 35-42). Kota Bharu, Kelantan: Edusage Network.

Selvaratnam, V. (2018). Malaysia: National Language Policy and Employability. International Higher Education, 96, 16-18. https://doi.org/10.6017/ihe.2019.96.10776

Ting, S. H., Marzuki, E., Chuah, K. M., Misieng, J., \& Jerome, C. (2017). Employers' Views on Importance of English Proficiency and Communication Skill for Employability in Malaysia. Indonesian Journal of Applied Linguistics, 7, 315-327. https://doi.org/10.17509/ijal.v7i2.8132

Ujang, A. (2019). Malaysians Struggling with English, Cut the Cuff. The Sun Daily, 4 January.

https://www.thesundaily.my/opinion/malaysians-struggling-with-english-FC433412

Zulkiflei, K., Yunus, M. M., \& Hashim, H. (2017). Positive Attitude Makes Good English. Really. In International Conference on Education and Regional Development. 